Production

ENGINEERING ARCHIVES
2015,Vol. 7, No 2, pp 20-24

ISSN 2353-5156 (print version)

ISSN 2353-7779 (online version)

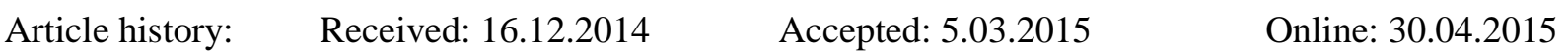

\title{
The Mystery Shopper Technique as a way of improving hotel gastronomy services
}

\author{
Ewa Wszendybyl-Skulska ${ }^{1}$ \\ ${ }^{1}$ PhD., Jagiellonian University, Faculty of Management and Social Communication, Department of Management in Tourism e-mail: \\ ewawszendybyl@wp.pl; e.wszendybyl-skulska@uj.edu.pl
}

\begin{abstract}
The problems connected with the issue of service quality is an important aspect in the service industry, however it is difficult to measure. It may be quite difficult to estimate it unequivocally and objectively due to the fact that each service includes more or fewer material elements. It is impossible to improve something that has not been measured and estimated before and one does not know whether it fulfils the requirements. Hotel gastronomy services are a kind of service that are partly materialized which makes the quality estimation easier. Nevertheless, one ought to remember that they are also shaped by non-material elements that influence the final quality estimation which seems to be problematic. The so-called Mystery Shopper Technique as a way of improving the quality of hotel gastronomy services is presented in the article.
\end{abstract}

Key words - quality, gastronomy services, mystery shopper

\section{Introduction}

Customer satisfaction and service level are measured in two ways, both in Poland and worldwide. The first one means leaving questionnaires with several questions to answer in hotel rooms or at the reception desk. The other one is a so-called "mystery shopper" method. The disadvantage referring to the first way is that most hotel guests do not pay too much attention to questionnaires - according to studies of the examination, it is only filled in by a small fraction of all customers (OLSZEWSKI K. 2004). Some hotels send sheets of questionnaires to their customers several days after their stay at a certain hotel. Although hotels are able to gain a general impression here, details always fade somehow and clients do not remember such facts as e.g. a cracking door. Naturally, it does not mean that hotel-keepers should give up sending or giving ques- tionnaires to their customers. In this way they consider customers' opinions essential. However, results of the questionnaire survey carried out among hotel customers ought to be supplemented by the research conducted by a "mystery shopper".

The "mystery shopper" method is a popular tool to estimate standards of customer service in West European countries and in the USA. Mystery shopping is becoming an accepted and highly utilized tool for service quality control, currently used in a multitude of industries, including travel and tourism (FELERTAG $\mathrm{H}$. 2007), retail (FINN A. 2001), banking and financial services (ŁAWICKI J.S. 2007). Only in the United States there are over 500 auditor enterprises tackling the "mystery shopping" method in hotels. They provide services to the, first of all, international hotel systems i.e. Starwood, Marriott, Hyatt. However, small 
and medium-sized enterprises, that are a prevailing group on the Polish and global market, seem to be more and more interested in that way of quality measurement referring to the offered services (BEDNARCZYK M. 2006).

Examinations with the "mystery shopper" method give an estimation of services from a customer's point of view (ZIELIŃSKI P. 2004). That is why an auditor, that is a person playing a role of a typical average customer behaving according to the settled scheme, is so significant here (WÓDKOWSKI A. 2004). An auditor should be a person looking like a typical guest of an examined object, that, staying at it, is making notes using a specially constructed form. In that kind of quality measurement it is important to pick up a suitable "customer" so as not to arouse suspicion of the staff that should know nothing about the examination. A person that is driving a luxurious car, wearing very smart clothes and paying by gold credit card mustn't be sent to a two-star hotel. It would be too suspicious for that kind of guest would not match the profile of customers visiting the examined hotel. A similar situation may occur when a poor customer parks his old wrecked car in front of a luxurious hotel.

A "mystery shopper", while visiting a hotel, sees its employees in their natural work conditions and practical situations, setting himself into the group of visitors. However, to make the measurement reliable, another person who would officially check a typical stay at the hotel and the kinds of people staying at it, should be sent before a relevant visit of an auditor. After the profile of visitors is checked, a properly chosen "customer" is sent. The main task of the "mystery shopper" is to cause some controversial situations and check how the hotel staff react and cope with them. It ought to be remembered that the mystery shopper mustn't be aggressive so that they would be afraid of him/her (WSZENDYBYE-SKULSKA E. 2008).

A wide range of organizations use this approach to provide a reliable measure of performance relative to service standards established by their management teams. In particular, mystery shopping results are used for three main purposes (WILSON A. M. 2001):

- To act as a diagnostic tool identifying failings and weak points in an organization's service delivery.
- To encourage, develop and motivate service personnel by linking with appraisal, training and reward mechanisms.

- To assess the competitiveness of an organization's service provision by benchmarking it against the offerings of others in an industry.

Depending on which of the above aims is chosen, the examination standards are created. The standards are identified with the standards held in the examined enterprise. Some hotels, mainly the high standard ones that belong to the hotel nets, have precisely defined standards referring to customer service. The directives included in the standards most frequently refer to the maximum time a customer spends at the reception desk as well as to the delivery time of a "room service" order or a welcoming formula during a phone call.

In case a given company does not have precisely elaborated standards, all possible examinations on a customer service ought to be analyzed and the applied methods of customer satisfaction and expectation measurement should be recognized. In case none of the examinations is applied, the mystery shopper method ought to undertake discussion groups or interviews with customers (WÓDKOWSKI A. 2004).

\section{Service quality measurement in hotel gastronomy}

Mystery shopping is used to measuring the process, emphasizing the service experience as it unfolds, and focusing on procedures and activities that occur or don't occur. Mystery shopping aims to collect facts rather than opinions (WILSON A.M. 2001).

The "mystery shopper" technique is applied, first of all, to examine the standards referring to a customer service as well as to the way the staff behave during critical and atypical situations. Thereby, it is a perfect way to measure levels of gastronomic services provided by hotels. Gastronomic services are a significant source of profits for hotels. In high standard hotels they determine from $35.7 \%$ to $43 \%$ of a total sale (SALA J. 2004). It means shaping the size and structure of hotel profits, hotel gastronomy enlarges profits gained from tourist services not only within a hotel as well as influences the effectiveness of its activity. Attention ought to be particularly paid to the quality of the dishes offered, not only from the range of health 
protection of the food offered by implementation of the HACCP system (WSZENDYBYŁ E. 2004) but also from the point of view of service quality.

For that purpose an examination on a service quality level in a gastronomic part of one of the medium-sized Polish hotels was carried out.

The object of investigation is a family hotel which does not have, at the moment of examination, any elaborated standards of customer service. In connection with a lack of strictly defined standards there was a necessity to analyze the methods of customer satisfaction and expectation measurement. After the conversation with both the owner and the staff of the examined object it was proved that the only method of collecting guests' opinions are individual conversations led by the owner and the Book of Complaints.

Based on the analysis of the remarks written in the Book of Complaints, conversations with the owner and the staff and with the customers, the form of an audit was elaborated. The tool of examination (i.e. the form of an audit) consisted of 155 precisely and clearly defined standards referring to the entire area of gastronomic activity of the object (the restaurant, room service, bar) that allow the auditor to give an unambiguous response (Table 1).

The measurement of quality of gastronomic services offered by the analyzed hotel with the mystery shopper method was scored 0 (very poor) to 6 (very good). The auditor's job does not count on estimation of the food quality. Such a job is usually done by tasters and critics in newspapers. In this case, the auditor examined the quality of a service. However, in case they were given cold soup or an overdone chop it would become a fact and would not be a subject of discussion.

The next stage of the examination of quality of gastronomic services offered by the analyzed object was choosing a suitable auditor. During the tentative conversation with the owner and staff of the examined object one recognized the profile of a typical average customer of the object. The hotel was most frequently visited by employees of big businesses in their mid 30s, travelling by business car and making some tentative conversations with contractors at the hotel. Therefore, the auditor playing the role of the mystery shopper was a 31-year-old female, an employee at an advisory firm and travelling by business car.
During the three-day stay at the hotel she made observations completing the form not to make the hotel staff suspicious.

The auditor must not have written any notes during observations as it would be too suspicious for the hotel personnel. However, it was easier for the "mystery shopper" to observe everything because even if, at the first time, she hadn't checked how the standards had been complied, she could have done it during the second or third visit of the three-day stay.

After the observations were made and the form was completed the auditor undertook the analysis. The results of the analysis were presented in the report and then shown to the owner of the hotel. The results from the report suggest the restaurant is thought to be pleasant and comfortable and the menu is very complex as it includes a great number of regional dishes.

However, immediately after the auditor entered the restaurant there was no welcome service. She had to choose a table herself. Later the service at the table was efficient and professional during the meal. The dishes were very tasty. In view of a strongly complex number of standards both Table 14.1 and the report include only the estimation and quality analysis of the service at the hotel restaurant.

As it results from the data collected in Table 1 and in the part of the report, the appointed standards were fulfilled $84.28 \%$ of the time. The result means the service was well estimated by the guest at the restaurant. However, to improve the result, there is a recommendation to have the continuous presence of at least one waiter at the restaurant as it is unknown when a guest enters the room and wishes to place the order (WSZENDYBYE_SKULSKA E. 2008).

According to the obligatory standards, gastronomic services should be available at the hotel $24 / 7$ not necessarily at the restaurant. Thus, if a guest was informed about the opening hours of the hotel restaurant they would expect to use it without the necessity of waiting for the service. 
Table 1. A fragment of the audit questionnaire referring to the quality of the services offered by the hotel restaurant

\begin{tabular}{|c|c|c|c|c|}
\hline O.N. & $\begin{array}{l}\text { Restaurant } \\
\text { service }\end{array}$ & $\begin{array}{l}\text { Max. } \\
\text { amo- } \\
\text { unt of } \\
\text { points }\end{array}$ & Note & $\begin{array}{l}\text { Auditor's } \\
\text { remarks }\end{array}$ \\
\hline 1. & $\begin{array}{l}\text { kind/ warm(with a } \\
\text { smile) welcome } \\
\text { by the staff at the } \\
\text { entrance to the } \\
\text { restaurant }\end{array}$ & 6 & 0 & $\begin{array}{l}\text { At the entrance to } \\
\text { the restaurant and } \\
\text { inside none of the } \\
\text { personnel was } \\
\text { present for } 10 \\
\text { minutes }\end{array}$ \\
\hline 2. & $\begin{array}{l}\text { The query about } \\
\text { the preferences } \\
\text { connected with } \\
\text { the location (a } \\
\text { Table) in the } \\
\text { smoking / non- } \\
\text { smoking area }\end{array}$ & 4 & 0 & ditto \\
\hline 3. & $\begin{array}{l}\text { Accompanying a } \\
\text { guest to the Table }\end{array}$ & 6 & 0 & ditto \\
\hline 4. & $\begin{array}{l}\text { The open menu } \\
\text { passed promptly }\end{array}$ & 6 & 0 & ditto \\
\hline 5. & $\begin{array}{l}\text { Relatively short } \\
\text { time of the order } \\
\text { realization }\end{array}$ & 6 & 6 & \\
\hline 6. & $\begin{array}{c}\text { The waiter can } \\
\text { answer the ques- } \\
\text { tions referring to } \\
\text { the ordered dishes } \\
\text { and beverages, he } \\
\text { knows what 'the } \\
\text { special of the } \\
\text { day" is }\end{array}$ & 6 & 6 & \\
\hline 7. & $\begin{array}{l}\text { Relatively short } \\
\text { time of the order } \\
\text { realization }\end{array}$ & 6 & 6 & \\
\hline 8. & $\begin{array}{l}\text { The waiter deliv- } \\
\text { ered the food } \\
\text { compatible with } \\
\text { the order }\end{array}$ & 4 & 4 & \\
\hline 9. & $\begin{array}{c}\text { Kind and profes- } \\
\text { sional waiter } \\
\text { service } \\
\end{array}$ & 6 & 6 & \\
\hline 10. & $\begin{array}{l}\text { Suitable tempera- } \\
\text { ture of the dishes }\end{array}$ & 4 & 4 & \\
\hline 11. & $\begin{array}{l}\text { Aesthetic presen- } \\
\text { tation of the } \\
\text { delivered dishes }\end{array}$ & 4 & 4 & \\
\hline 12. & $\begin{array}{c}\text { Mucky plates } \\
\text { immediately } \\
\text { collected during } \\
\text { eating }\end{array}$ & 6 & 6 & \\
\hline 13. & $\begin{array}{l}\text { While having the } \\
\text { meal the waiter } \\
\text { makes sure the } \\
\text { guest is satisfied } \\
\text { with the given } \\
\text { dish }\end{array}$ & 4 & 4 & \\
\hline 14. & $\begin{array}{c}\text { The personnel } \\
\text { runs a suggestive } \\
\text { sale: advises what } \\
\text { to eat or/and drink }\end{array}$ & 6 & 6 & \\
\hline 15. & $\begin{array}{c}\text { The bill was } \\
\text { properly edited }\end{array}$ & 6 & 6 & \\
\hline 16. & $\begin{array}{c}\text { The bill was } \\
\text { passed in a case }\end{array}$ & 2 & 2 & \\
\hline
\end{tabular}

\begin{tabular}{|c|c|c|c|c|}
\hline 17. & $\begin{array}{l}\text { No sounds from } \\
\text { the background or } \\
\text { no voices of the } \\
\text { staff were heard } \\
\text { inside the restau- } \\
\text { rant }\end{array}$ & 6 & 6 & \\
\hline 18. & $\begin{array}{l}\text { The door to the } \\
\text { restaurant back- } \\
\text { ground were } \\
\text { closed }\end{array}$ & 4 & 4 & \\
\hline 19. & $\begin{array}{l}\text { At the exit of the } \\
\text { restaurant the staff } \\
\text { kindly/warmly } \\
\text { thank the guest }\end{array}$ & 6 & 6 & \\
\hline 20. & $\begin{array}{c}\text { Work quietly and } \\
\text { effectively }\end{array}$ & 6 & 6 & \\
\hline 21. & $\begin{array}{l}\text { Wear homogene- } \\
\text { ous uniforms } \\
\text { according to the } \\
\text { accepted standard } \\
\text { (the uniforms and } \\
\text { shoes are well } \\
\text { maintained) }\end{array}$ & 6 & 6 & \\
\hline 22. & $\begin{array}{l}\text { Are smart and } \\
\text { elegant (they care } \\
\text { about their looks } \\
\text { and hygiene) }\end{array}$ & 6 & 6 & \\
\hline 23. & $\begin{array}{l}\text { Have identifiers } \\
\text { according to the } \\
\text { standard }\end{array}$ & 6 & 6 & \\
\hline 24. & $\begin{array}{l}\text { The staff are } \\
\text { smiling, hospita- } \\
\text { ble, open for } \\
\text { guests }\end{array}$ & 6 & 6 & \\
\hline 25. & $\begin{array}{l}\text { The restaurant } \\
\text { seems to be } \\
\text { comfortable, there } \\
\text { is a nice atmos- } \\
\text { phere there }\end{array}$ & 6 & 6 & \\
\hline 26. & $\begin{array}{l}\text { The range of the } \\
\text { offered dishes is } \\
\text { wide enough }\end{array}$ & 6 & 6 & \\
\hline & Total & 140 & 118 & \\
\hline
\end{tabular}

Source: author's own elaboration presented WSZENDYBYŁSKULSKA EWA, Improvement of quality of hotel gastronomy services, [in:] Quality and production management in practice, Saint Petersburg 2008, s. 87-92

An auditor's duty, except for giving a general opinion and analysis of the collected results, is to elaborate the suggested corrective or preventive activities in relation to the identified discrepancies.

After the research had been completed and the final report with the recommendations had been delivered to the owner of the hotel, the results of the examination were presented to the staff by the owner. The examination of quality of the service at the gastronomical part of the hotel with the "mystery shopper" method was not supposed to point out who is not doing their job correctly but to point out any possible faults. 


\section{Summary}

The examination by the "mystery shopper" method means writing down facts and observations. The auditor checks how long one needs to wait until a waiter approaches the table, how long the breaks between the served dishes are and vocabulary the waiter uses. Therefore, the basic advantage of such a method of measurement is natural conditions in which the research is conducted.

The use of mystery shoppers should be done in an open and transparent way. By giving information on the use of mystery shoppers throughout the organization, it gives stimulus to pay greater attention to observing customers. Well communicated results can also create a positive drive for improvements in the organization (HESSELINK M., VAN IWAARDEN J., VAN DER WIELE T. 2004).

Besides, the "mystery shopper" method allows an organization, not only to estimate the quality of the services offered and grade the standards, but also to monitor all changes of the activity. If the examinations with the "mystery shopper" method are conducted systematically and the results are open to the employees, they may become an effective tool to demonstrate to employees how to perform better.

Hotel keepers conducting examinations on the quality of the offered services in their business should always remember that the decision about necessary changes must not be based solely on the results obtained from a single examination, especially when only one method is used. Such results do not always reflect an actual state. In case any decisions about changes are made, they should be first based on information coming from many elaborations and analyses.

\section{References}

1. BEDNARCZYK M.(ED.). 2006. Konkurencyjność matych $i$ średnich przedsiębiorstw na polskim rynku turystycznym. Wydawnictwo Uniwersytetu Jagiellońskiego. Kraków.

2. Felertag H. 2007. Sales managers fail to respond to inquiries. Hotel \& Motel Management 10.

3. FINN A. 2001. Mystery shopper benchmarking of durable-goods chains and stores. Journal of Service Research $3(4)$.

4. http://repub.eur.nl/res/pub/1737/ERS\%202004\%20082\% 20ORG.pdf, HESSELINK M., VAN IWAARDEN J. VAN DER WIELE T. 2004. Mystery shopping: A tool to developinsight into customer service provision.

5. ŁAWICKI J.S. 2007. Badanie jakości obstugi bankowej. Marketing w praktyce 8.

6. OlsZEWSKI K. 2004. Uwaga: tajemniczy klient. Świat Hoteli 1.

7. SALA J. 2004. Marketing w gastronomii. PWE. Warszawa.

8. Wilson A. M. 2001. Mystery Shopping: Using Deception to Measure Service Performance. Psychology \& Marketing 18.

9. WóDKOWSKI A. 2003. Tajemniczy klient wkracza do badań. Marketing w praktyce 1.

10. WSZENDYBYŁ E. 2004. Bedeutung des HACCP - Systems für die Kunden der Hotelgastronomie. Letna Skola Unavy Materialov'2004. VII Rocnik, Zuberec-Rohace.

11. WSZENDYBYŁ-SKULSKA E. 2008. Improvement of quality of hotel gastronomy services. Quality and production management in practice, Saint - Petersburg.

12. ZIELIŃSKI P. 2004. Tajemniczy klient $w$ hotelu. Hotelarz 4. 